\title{
Wspólna przestrzeń. Wokół tematów żydowskich - uwagi wstępne
}

\section{A Common Space: On Jewish Subjects - Some Preliminary Remarks}

Od czasu opublikowania szkicu Jana Błońskiego Biedni Polacy patrza na getto minęły 32 lata, jednak zapoczątkowana wówczas dyskusja trwa, rozwija się, budzi emocje nie mniejsze niż na początku. Im więcej mówimy o relacjach polsko-żydowskich, tym bardziej widoczna staje się rozległość problematyki i jej złożoność. Powstają wciąż nowe opracowania, realizowane są kolejne projekty naukowe, działają instytucje ukierunkowane na popularyzowanie wiedzy o dziejach Żydów w Polsce, o współtworzeniu przez nich polskiej kultury, ale także o znaczeniu ich obecności dla tożsamości Polaków. Żydów nad Wisłą dziś prawie nie ma, a jednak żyją w polskiej świadomości, budząc z jednej strony zainteresowanie, z drugiej - co szczególnie zasmuca - najgorsze antysemickie stereotypy. Refleksję nad tą obecnością/nieobecnością podejmuje również literatura. Poruszając temat wspólnej przestrzeni Polaków i Żydów, chcieliśmy włączyć się w dyskusje, które na nowo z niezwykłą siłą rozgorzały w 50. rocznicę Marca 1968, i podjąć wielokierunkowy namysł związany nie tylko z pytaniem o polskie winy i grzechy, choć od tych pytań uciec nie można.

Rozpoczynamy od tekstu, który sięga do czasów Drugiej Rzeczpospolitej i przedstawia pisarzy patrzących na Polskę i Żydów w Polsce z zewnętrznej perspektywy. Marion Brandt rozpatruje literackie obrazy stworzone przez Josepha Rotha w Listach z Polski i Żydach na tutaczce niejako w odpowiedzi na Podróż po Polsce Alfreda Döblina. Wymienione książki Rotha trafiły do polskiego czytelnika dopiero ostatnio - wydane przez Austerię w 2017 i 2018 roku. Analizując paralele między wizerunkami Żydów kreślonymi przez Döblina i Rotha, autorka artykułu wskazuje na tak istotne kwestie, jak pytanie o rolę syjonizmu, o koncepcje państwa narodowego, ale może przede wszystkim o to, jak Zachód Europy postrzegał wschodnioeuropejskich Żydów. Obrazy te tworzą z jednej strony pisarz niemiecki, z drugiej - austriacki. Obaj wywodzili się 
z rodzin żydowskich, ale opisywany świat jest znacznie bardziej znany i bliski Rothowi. Refleksje tych autorów, sposób, w jaki przedstawiają młode polskie państwo i jego problemy, stanowią istotne tło rozważań o kształtowaniu się stosunków polsko-żydowskich.

Przenikanie obu światów w literaturze częściej bywało rozpatrywane pod kątem obecności szeroko rozumianej tematyki żydowskiej w literaturze powstającej w języku polskim. Karolina Koprowska w swoim tekście proponuje inne ujęcie: omawia twórczość Awroma Suckewera piszącego w jidysz, a przedmiotem swojego zainteresowania czyni relację podmiotu i krajobrazu w jego wczesnej liryce. Akcentując epifaniczny charakter doświadczeń, wskazuje na związki tej poezji z polską tradycją romantyczno-modernistyczną. Choć wiedza o polsko-żydowskich pisarzach tworzących w jidysz jest systematycznie pogłębiana i upowszechniana - w ostatnich latach powstały na przykład książka Magdaleny Ruty o Kalmanie Segalu ${ }^{1}$, antologia poetek jidysz ${ }^{2}$, prace zbiorowe i artykuły między innymi Joanny Lisek, Eugenii Prokop-Janiec, Karoliny Szymaniak i wielu innych - nadal nie jest znana szerszemu gronu odbiorców.

Wśród zagadnień związanych z egzystencją Polaków i Żydów we wspólnej przestrzeni największe zainteresowanie i emocje ze zrozumiałych względów budzi czas Zagłady. Sławomir Buryła prezentuje syntetyczne ujęcie obrazu getta warszawskiego w polskiej literaturze i wskazuje na możliwość klasyfikacji utworów podejmujących ten temat. Kreśląc szeroką panoramę, badacz omawia zmiany, które zachodzą w literackim obrazie getta od lat czterdziestych aż po czasy najnowsze. Kontekst historyczny, wpływ ideologii, światopogląd autorów, wreszcie mijający czas są czynnikami kształtującymi zarówno sposób przedstawiania realiów życia w getcie, jak i towarzyszący mu komentarz.

Pamięci o Zagładzie utrwalonej w literaturze dotyczy także szkic Małgorzaty Golik. Poświęca ona uwagę utworom tak zwanego trzeciego pokolenia polskich Żydów, w szczególności twórczości Piotra Pazińskiego. Analizując teksty literackie, w których pamięć o żydowskim pochodzeniu, o nieistniejącym już świecie jest tematem dominującym, autorka wskazuje na cechy charakterystyczne tego ujęcia i akcentuje różnice między spojrzeniem tej młodszej generacji a perspektywą właściwą ich rodzicom. Istotne zagadnienia poruszane w tym kontekście to problemy: traumy, jej wpływu na życie, tożsamości potomków ocalałych oraz sposobu ujmowania tych doświadczeń w języku literatury.

Relacji między Polakami a Żydami ujmowanej przez pryzmat antysemityzmu dotyczy tekst Jacka Leociaka będący komentarzem do książki Joanny Tokarskiej-Bakir Pod klatwa. Spoteczny portret pogromu kieleckiego. Autor powraca do podstawowych faktów, czyni to jednak, rozpoczynając od zestawienia dwóch fotografii: ofiar z pogromu w Wilnie w 1919 roku i w Kielcach w 1946.

${ }^{1}$ M. Ruta, Pomiędzy dwoma światami. O Kalmanie Segalu, Kraków 2003.

${ }^{2}$ Moja dzika koza. Antologia poetek jidysz, tłum. P. Appenszlak i in., wyb., oprac. K. Szymaniak, J. Lisek, B. Szwarcman-Czarnota, Kraków-Budapeszt-Syrakuzy 2018. 
Ukazując te dwa emblematyczne wizerunki, ujmuje symbolicznie wszystkie wydarzenia pogromowe. W refleksji wybrzmiewa przekonanie o powtarzalności schematów i zachowań, tym bardziej gorzkie, że wsparte konstatacją o aktualności tej problematyki. Autor artykułu prezentuje książkę Tokarskiej-Bakir w kontekście znanych już badań, podkreślając wartość kwerendy archiwalnejgłosów świadków, uczestników. Jednak największą uwagę skupia na wyłaniającej się z dokumentów genezie relacji między Polakami a Żydami, roli Kościoła Katolickiego i na czynnikach konstytutywnych modelu dyskursu katolicko-narodowego. Szkic jest ważnym głosem akcentującym konieczność refleksji, która dotyczy wszystkich Polaków.

Blok tekstów poświęconych tematom żydowskim zamyka dwugłos o ksiązce Joshui D. Zimmermana Polskie Państwo Podziemne i Żydzi w czasie II wojny światowej. Andrzej Żbikowski w swojej recenzji docenia wartość publikacji. Charakteryzując sposób prezentacji tematu przez autora monografii, podkreśla wpływ właściwej Zimmermanowi perspektywy zewnętrznej i wchodzi w polemikę z ujęciem, które jego zdaniem zbyt wyrozumiale ocenia stosunek środowisk AK do Żydów. Joshua D. Zimmerman w odpowiedzi Andrzejowi Żbikowskiemu wyjaśnia swoje stanowisko, postulując konieczność wyważonej (niezależnej od intencji perswazyjnych) oceny zaangażowania AK w pomoc Żydom.

Różnorodność prezentowanych tematów ma w naszym zamierzeniu unaocznić wielość kierunków refleksji związanych z relacjami polsko-żydowskimi.

W zeszycie zamieszczamy też artykuły niezwiązane z głównym tematem: wnikliwą prezentację Dziennika nieciagtego Zygmunta Lubicz-Zaleskiego przygotowaną przez Karola Samsela, szczegółowe rozważania Magdaleny Lachman o tym, kim jest dziś pisarz w (pop)kulturze, oraz recenzję autorstwa Jacka Łukasiewicza o książce Anny Spólnej Dialogi z Mickiewiczem. 